\title{
Multi-Drug Resistance Genes associated with some Gram-Negative Bacterial Isolated from Shellfish in Iko and Douglas River Estuaries, in Nigeria
}

\author{
Nsikan Samuel udoekong ${ }^{1}$, Bassey Enya Bassey*², Anne E Asuquo ${ }^{3}$, Otobong Donald Akan ${ }^{4}$, \\ Casmir Ifeanyichukwu Cajetan Ifeanyi $^{5}$ \\ ${ }^{1}$ Science Technology Department, Akwa Ibom State Polytechnic, Ikot Osurua, Nigeria \\ ${ }^{2}$ World Health Organization Nigeria Country Office, Garki, Abuja, Nigeria \\ ${ }^{3}$ Department of Medical Laboratory Science, University of Calabar, Cross River State, Nigeria \\ ${ }^{4}$ Microbiology Department, Akwa-Ibom State University, Ikot Akpaden, Akwa-Ibom State, Nigeria. \\ College of Food Science and Engineering, Central South University of Forestry and Technology, \\ Hunan, China \\ ${ }^{5}$ Department of Veterinary Microbiology, Faculty of Veterinary Medicine, University of Abuja, \\ Nigeria
}

*Corresponding Author: Bassey Enya Bassey, World Health Organization Nigeria Country Office, Garki, Abuja, Nigeria.

\begin{abstract}
Background: Multi drug resistant bacterial agents that contaminate seafood cause several diseases in humans and are widely documented as a global public health challenge.

Methods: This study evaluated the microbiological and antimicrobial resistance genes profiles of bacterial Isolates from shellfish vended at Iko and Douglas Creeks of Cross River State, Nigeria. A total of 540 shellfish (117 clams, 88 oysters, 136 periwinkles) samples were collected from various vendor at the two Creeks were analyzed. The samples were processed using standard microbiological methods to identify bacterial pathogens. Antimicrobial susceptibility was assayed using the Kirby-Bauer disk diffusion method. Isolates were screened for antimicrobial resistant genes using polymerase chain reaction.

Results: Overall, a total of 135 bacteria isolates were identified. The most common isolate was Alcaligenes species 53(39.2\%) followed by Pseudomonas species 44(32.6\%), Providencia species 25(18.5\%), Vibrio species 6(4.4\%), and Paenalcaligenes species 7(5.2\%). The isolates showed varying susceptibilities to Imipenem (36\%) and amikacin (28\%) but were all resistant to Trimethoprim-Sulfamethoxazole. Fifty-three isolates had a multiple antibiotic resistance index (MARI) of $\geq 0.9$ - 1.0. Most of the bacterial isolates were detected with TEM genes (82.2\%), SHV (51.8\%), VIM (50.3\%) resistance genes. None of the isolates expressed Veb gene. Only 40.7\% of the isolates expressed QnrB gene while none expressed QnrA and QnrS.

Conclusion: The detection of these multidrug resistant clinically relevant bacterial species suggests a significant linkage of commonly consumed seafood in the community and environmental spread of MDR bacteria.
\end{abstract}

Keywords: Shellfish, aminoglycoside, MARI, phenotypic, Gram-negative bacteria, PCR

\section{INTRODUCTION}

Multi-drug resistant bacteria among foodborne pathogens has become a matter of great public health concern [1]. It is estimated that unsafe food containing harmful bacteria, viruses, parasites or chemical substances, causes more than 200 diseases - ranging from diarrhoea to cancers. [2].

The world Health Organization, reported in 2017 that the global burden of food borne diseases each year was as many as 600 million, or almost 1 in 10 people in the world, fall ill after consuming contaminated food. Of these, 420,000 people die, including 125,000 children under the age of 5 years [2].

Globally, various bacterial pathogens affect a wide range of aquatic species and are responsible for considerable economic losses [3]. Foodborne bacterial infections caused by resistant bacteria are difficult to treat because of it being unsusceptible to even last resort antibiotics [4]. It is estimated that by the year 2050 about 10 million people globally will die 
from resistant infections [5]. World-wide, the rate of spread of antimicrobial resistance has become worrisome with alarming increase in the number and types of environmentally disseminated antimicrobial resistances (AMR) which has become a major risk to human health $[5,6,7,8]$. Notably, due to their distinctive structure, the Gram-negative bacteria (GNB), in non-negligible numbers, manifest concomitant resistance more than Gram-positive bacteria to all commonly used classes of antimicrobials leading to significant morbidity and mortality [9].

Antibiotics used therapeutically and prophylactically in animal production for different purposes are the main route for its dissemination in the environment [10]. The use of antibiotics in aquaculture is well-known to results in the selection of proliferated antibioticresistant bacteria possessing mobile genetic elements such as transposons, plasmids, integrons and gene cassettes which through horizontal gene transfer can be transferred to the whole environment [11]. Environmental dissemination of antibiotics particularly in aquatic environments potentiates antibiotic pressure and, promotes the dissemination of antibiotic resistant bacteria (ARB) and antibiotic resistance genes (ARGs) [4, 10, 12]. As has been proven over time, drug resistant genes transfers can spontaneously occur from nonhuman pathogenic bacteria to human pathogens co-existing in the same environment [13].

Antimicrobial resistance by multi-drug resistant Gram-negative bacteria (MDRGN) is mostly plasmid mediated and several different species are involved [14]. These resistance traits can be transferred from individual bacteria to other individual bacteria, and in rare cases even between species [15.16]. The mechanism of resistance especially in Gram negative bacilli arises from the expression of antibiotics activating enzymes and non-enzymatic pathways [17]. Often, these results from the intrinsic resistance due to mutations in chromosomal genes (such as increasing the expression of antibiotic-inactivating enzymes, efflux pumps, permeability or target modifications) or acquisition by transfer of mobile genetic elements carrying resistance genes such as plasmid encoding $\beta$-lactamases, aminoglycosides modifying enzymes, or nonenzymatic mechanisms like Qnr (plasmid-borne quinolone resistance gene) for fluoroquinolone (FQ) resistance in Enterobacteriaceae [18].
Though integral to the epidemiology of antimicrobial resistance, the aquatic ecosystem has not been adequately studied [19]. Secondary contamination of fresh seafood with enteric bacteria resistant to multiple antibiotics may implicate seafood as a potential carrier of antibiotic resistant bacteria and emphasizes an urgent need to prevent environmental contamination and dissemination of such bacteria [20]. Commonly consumed seafood as carriers of multidrug-resistant bacteria has been underscored as a growing human threat causing wider dissemination of MDR-bacteria in the community and potentially can result in the transfer of resistant determinants to other clinically important bacteria $[1,20,21$,$] .$ Seafood is relatively free of human pathogens, except for Vibrios which are natural contaminants of seafood from the marine environment [20]. In most part of Nigeria, these shellfish types - clams, oysters, periwinkles as a good source of dietary protein. Even so, not much is known regarding the health implications of human consumption of these shellfish vended at Iko and Douglas Creeks of Cross River State, Nigeria. In this sense, the need to assess and investigate the potential risk posed to human health by consuming these shellfish cannot be overemphasized. Much more efforts are required to fully explore the connectivity of the aquatic environment and hence the intrinsic linkages between humans, animals and the environment in the global AMR dissemination [22]. The "One Health" approach, a holistic and multisectoral approach, is also needed to address AMR's rising threat [23]. Therefore, screening, monitoring and surveillance for antimicrobial resistance pattern of bacterial pathogens derived from seafood from aquatic sources is key in helping to prevent human health risks from seafood consumption. This study evaluated the microbiological and antimicrobial resistance genes profiles of bacterial Isolates from shellfish vended at Iko and Douglas Creeks of Cross River State, Nigeria.

\section{METHOdOLOGY}

\section{Study Area}

The study is an experimental analysis carried out within the catchment of Iko and Douglas Creeks, Akwa Ibom State, in the South-South region of Nigeria. It is located between Latitude $4^{\circ} 321$ and $5^{\circ} 331$ North and Longitudes $7^{\circ} 251$ and $8^{\circ} 251$ East. The State has a population of over 5 million people, with a total area of 
$7,081 \mathrm{~km}^{2}$ (2,734 sq mi). The main occupational lines of the populace are farming, trading and fishing. It has two major seasons: wet and dry seasons. The State has the mean annual temperature of $80^{\circ} \mathrm{F}$ or $25^{\circ} \mathrm{C}$ and annual relative humidity of 70 to $80 \%$, with a mean annual rainfall of 3017 millilitres which favours agricultural practices. The State is drained by three major rivers; Qua Iboe River, Imo and Cross River respectively [24].

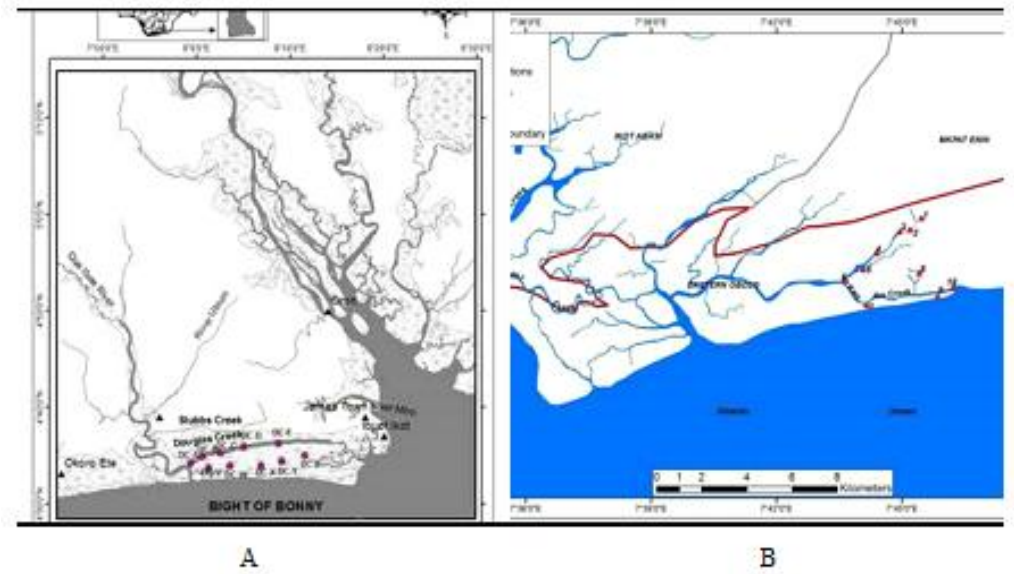

Map Showing Douglas (A) and Iko Creeks (B) Akwa Ibom State. Lfish

\section{Sample Collection/Processing}

In total, 117 clams, 88 oysters, 136 periwinkles were harvested from Iko and Douglas Creeks of Akwa Ibom State, Nigeria, during the rainy (March-July) and dry seasons (AugustFebruary) of the years 2015-2017. These samples were collected and placed in sterile iced-packed coolers and transported to the post graduate research laboratory, University of Uyo for bacteriological examination and analysis within 5 hours of each collection time. Initial processing of the shellfish included individual washing and scrubbing with a sponge in sterile water. These were then rinsed in $70 \%$ ethanol to remove adhered but external specks of dirt and debris. The shellfish were then shucked aseptically with a sterile shucking knife to remove the soft flesh. Subsequently, the flesh samples were individually dissected into body parts (flesh, intestine and gills) using sterile knives and scissors and homogenized using sterile plastic mortar and pestle. The protocols as in International Standard Organization [25] and Farmer et al. [26] were adopted for the bacteriology.

Bacterial isolation (Pre-enrichment, Enrichment and Plating).

Briefly, twenty-five $25 \mathrm{~g}$ of each shellfish homogenate were pre-enriched in $225 \mathrm{ml}$ of DEV lactose peptone broth (Merck Darmstadt, Germany) at $37^{\circ} \mathrm{C}$ in an incubator for 24 hours. An aliquot $(0.1 \mathrm{ml})$ of the pre-enriched culture were transferred using a sterile pipette into 10 $\mathrm{ml}$ of Meuller-Kauffmann tetrathionate broth
(MKTB), $10 \mathrm{ml}$ of Modified Semi-solid Rapapport-Vassilidis Agar (MSRV) and 1ml of same was copiously inoculated onto Thiosulphate Citrate Bile Salt Agar (TCBS). The inoculated tubes and plates were incubated at $37^{\circ} \mathrm{C}$ and $41^{\circ} \mathrm{C}$ for 24 hours respectively for further selective enrichment. The selectively enriched cultures were inoculated by spreading $0.1 \mathrm{~mL}$ of the incubated selective enrichment broth onto Xylose Lysine Deoxycholate Agar (XLD), Brilliant Green agar (BGA) and nutrient agar plates respectively and the plates were incubated at $37^{\circ} \mathrm{C}$ for 24 hours. Typical bacterial isolates were purified by streak plating on nutrient agar and incubated at $37^{\circ} \mathrm{C}$ for 24 hours. The discrete colonies formed were maintained on nutrient agar slants after subculturing as pure cultures and preserved in the refrigerator at $4{ }^{\circ} \mathrm{C}$ for further analysis.

\section{Characterization and identification of the isolates}

Purified typical colonies were characterized for identification using cultural, morphological and standard biochemical tests for identification of medical bacteria namely: Gram reaction, motility tests and standard biochemical tests such as; oxidase, urease, indole, VogesProskauer, hydrogen sulphide production, catalase, citrate utilization and sugar fermentation tests [27]. Biochemical Tests for Identification of Medical Bacteria. 3rd edition. New York, USA, Lippincott Williams \& Wilkins[28]. Bacterial isolates were further confirmed by molecular identification using the 
Multi-Drug Resistance Genes associated with some Gram-Negative Bacterial Isolated from Shellfish in Iko and Douglas River Estuaries, in Nigeria

universal 16S rRNA bacterial primers for microbiological identification of common bacterial pathogens. out using the universal $16 \mathrm{~S}$ rRNA bacterial primers [29].

\section{Antibiotic Susceptibility}

Identified bacterial strains we were tested for susceptibility to the following antibiotics: cefepime $(10 \mu \mathrm{g})$, nalidixic acid $(30 \mu \mathrm{g})$, ciprofloxacin $(5 \mu \mathrm{g})$, amikacin $(30 \mu \mathrm{g})$, imipenem $(30 \mu \mathrm{g})$, norfloxacin $(10 \mu \mathrm{g})$, trimethoprimsulfamethoxazole $(35 \mu \mathrm{g})$ and chloramphenicol $(30 \mu \mathrm{g})$, using the standard Kirby Bauer disk diffusion susceptibility testing method [30, 31]; Escherichia coli ATCC 25922 was used as a control. Detection of ESBL production was done using the following disks: cefotaxime $(30 \mu \mathrm{g})$, ceftriazone $(30 \mu \mathrm{g})$, cefpodoxime $(10 \mu \mathrm{g})$, ceftaxidime $(30 \mu \mathrm{g})$ and aztreonam $(30 \mu \mathrm{g})$. The zones of inhibition of each isolate were tested on Mueller-Hinton agar plates (Oxoid, Basingstoke, UK). Interpretive criteria established by the CLSI were used to categorize the results of antimicrobial susceptibility testing and ESBL production [32].

Multiple Antibiotic Resistance Index (MARI)

The multiple antibiotic resistance was calculated as follows:

MAR $=$ Ratio of number of antibiotics an isolate is resistant to (a)

Total number of antibiotics to which the organism is exposed to (b)

Take for an example; if A1 is resistant to 6 out of 8 antibiotics tested, the MAR index will be

- $M A R=a / b$;

Where $\mathbf{a}$ is the aggregate antibiotic-resistant score of an isolate and $\mathbf{b}$ the total number of antibiotics tested.

\section{DNA Extraction/Sequencing}

The bacterial genome was extracted using the method of Dashti et al. [33], with slight modifications as follows: the genomic extraction was carried out using the boiling method with a heating block at $95^{\circ} \mathrm{C}$ for 20 minutes. Plasmid DNA extraction was done using a Plasmid miniprep kit (Inqaba Biotechnology, Pretoria, South Africa). The sequencing of the amplicons was carried out according to the manufacturer's instructions on a $3510 \mathrm{AB} 1$ sequencer using the Big Dye Terminator Kit (Inqaba Biotechnology, Pretoria, South Africa).

\section{Amplification of the 16SrRNA genes}

The amplification of the 16S rRNA region of the isolates' rRNA genes of the isolates was carried out using the universal 16S rRNA bacterial primers $27 \mathrm{~F}$ (5'-AGAGTTTG ATCC TGGCTCAG -3') and 1392R (5'-GGTTA CCT TGTTACGAC TT-3') on an AB1 9700 Applied Biosystems thermal cycler with a final volume of $50 \mu \mathrm{l}$ for 35 cycles. The PCR mix used for the amplification was: X2 Dream Taq Master Mix supplied by Inqaba, South Africa (Taq polymerase, dNTPs, $\mathrm{MgCl}$ ), a $0.4 \mathrm{M}$ concentration of the primers and the extracted DNA being the template. The conditions required for the PCR amplification included: Initial denaturation at $95^{\circ} \mathrm{C}$ for 5 minutes; denaturation at $95^{\circ} \mathrm{C}$ for 30 seconds; annealing at $52^{\circ} \mathrm{C}$ for 30 seconds, extension at $72^{\circ} \mathrm{C}$ for 30 seconds for 35 cycles and a final extension at $72^{\circ} \mathrm{C}$ for 5 minutes. The product of this amplification was transferred onto a $1.0 \%$ agarose gel at $120 \mathrm{~V}$ for 20 minutes and a UV trans-illuminator was used for visualization of the bands.

\section{Amplification of qnr Genes}

The $q n r \mathrm{~A}, q n r \mathrm{~B}$ and $q n r \mathrm{~S}$ genes each were amplified on an AB1 9700 Applied Biosystems thermal cycler at a final volume of $50 \mu 1$ for 35 cycles. The PCR Mix was the X2 Dream TaqMaster mix supplied by Inqaba, South Africa (Taq Polymerase, DNTPS, Mg Cl), 0.4M concentration of Primers were used, and lastly, the extracted DNA was used as a template. The cycling conditions for amplification were as follows: Initial denaturation for 5 minutes at $95^{\circ} \mathrm{C}$; denaturation for 30 seconds at $95^{\circ} \mathrm{C}$; annealing at $52^{\circ} \mathrm{C}$ for 30 seconds; extension at $72^{\circ} \mathrm{C}$ for 30 seconds for 35 cycles and a final extension at $72^{\circ} \mathrm{C}$ for 5 minutes. The resulting PCR products were analysed by electrophoresis with $1.0 \%$ agarose gels in Tris-borate-EDTA buffer (TBE;Gibco, NT, USA) at $120 \mathrm{~V}$ for 20 minutes. Each gel was stained with ethidium bromide and bands produced were photographed on an ultraviolet light transilluminator. A molecular weight standard (100 bp and $1000 \mathrm{bp}$ ladder, Promega, Madison, USA) was included on each gel. The primer sequence used for the amplification of $q n r \mathrm{~A}, q n r \mathrm{~B}$ and $q n r \mathrm{~S}$ genes were:

qnr A/F: 51- TTCACGAAGATTTCTCA-31 qnr A/R: 51-GGCAGCACTATTACTCCCA-31 qnr B/F: 51-CCTGAGCGGCACTGAATTTAT31

qnr B/R: 51-GTTTGCTGCTTGCCAGTCGA-31 qnr S/F: 51-CAATCATACATATCGGCACC31

qnr S/R: 51-TCAGGATAAACAACAATACC C-31 
Multi-Drug Resistance Genes associated with some Gram-Negative Bacterial Isolated from Shellfish in Iko and Douglas River Estuaries, in Nigeria

\section{ESBL genes amplification}

The TEM, SHV and VIM genes were amplified using AB1 9700 Applied Biosystems thermal cycler at a final volume of $50 \mu 1$ for 35 cycles. The PCR Mix was the X2 Dream Taq Master Mix supplied by Inqaba, South Africa (Taq Polymerase, dNTPs, $\quad \mathrm{MgCl}_{2}$ ), $\quad 0.4 \mathrm{M}$ concentration of primers was used, and lastly, the extracted DNA was used as a template. The cycling conditions for amplification were as follows: initial denaturation for 5 minutes at $95^{\circ} \mathrm{C}$; another 30 seconds at $95^{\circ} \mathrm{C}$; annealing at $52^{\circ} \mathrm{C}$ for 30 seconds; extension at $72^{\circ} \mathrm{C}$ for 30 seconds for 35 cycles and a final extension at $72^{\circ} \mathrm{C}$ for 5 minutes. The resulting PCR products were analysed by electrophoresis with $1.0 \%$ agarose gels in Trisborate-EDTA buffer (TBE; Gibco, NT, USA) at $120 \mathrm{~V}$ for 15 minutes. The gels were stained with ethidium bromide and bands produced were photographed on an ultraviolet light transilluminator. A molecular weight standard (100 bp and $1000 \mathrm{bp}$ ladder, Promega, Madison, USA) was included on each gel.The primer sequence used for the amplification of TEM, SHV and VIM genes were:
TEMF: $5^{1}$ TCCGCTCATGAGACAATAACC- $3^{1}$ TEMR: $5^{1}$ ATAATACCGCACCACATAGCAG- $3^{1}$ $S H V F: 5^{1}$-TACCATGAGCGATAACAGGG $3^{1}$ $S H V R: 5^{1}$ - GATTTGCTGATTTCGCTCGG-3 ${ }^{1}$ VIM $F: 5^{1}$ TTATGGAGCAGCCAAGCAGTG $3^{1}$ VIMR: $5^{1}$ - CGAATGCGCAGCACCAGG

\section{DATA ANALYSIS}

The Statistical Package for Social Sciences (SPSS 22.0 Inc., Chicago, US) was used to analyze the data generated from this study. Pvalues of less than $0.05 \quad(\mathrm{P}<0.05)$ were considered statistically significant.

\section{RESUlTS}

One hundred and thirty-five bacterial agents isolated from the shellfish samples were identified to the genus level using standard microbiological methods including biochemical tests. Furthermore, molecular confirmation of all isolates was done by sequencing the PCR amplification of species-specific 16S rRNA gene and the results compared with the data in the NCBI gene Table 1.

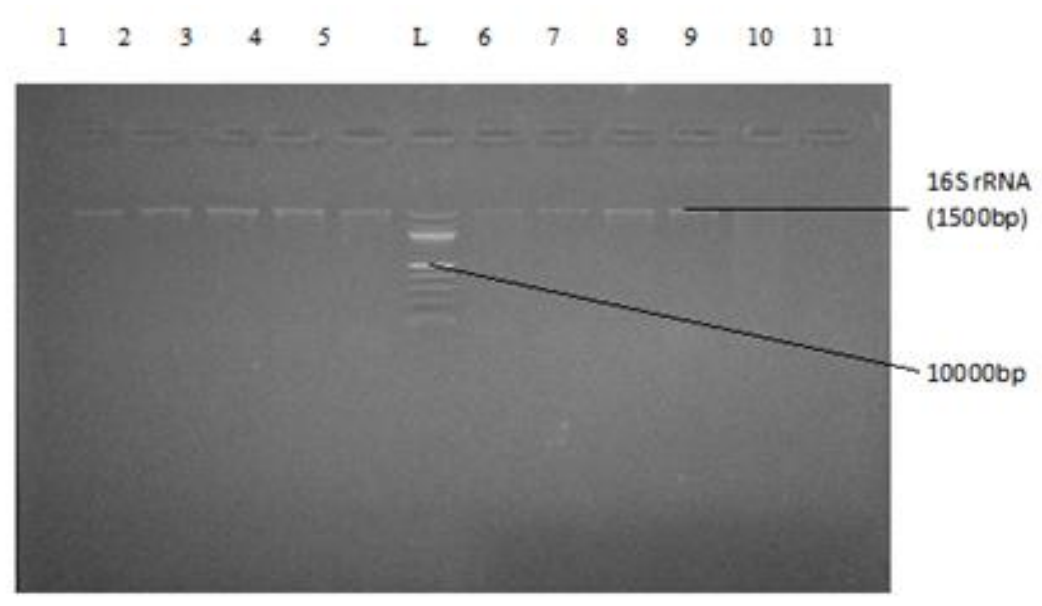

Fig1. Agarose gel electrophoresis showing the amplified 16S rRNA gene of the bacterial isolates. Lane L represents the 10,000bp molecular ladder

Table1. Identities of the bacterial isolates

\begin{tabular}{|l|l|l|l|}
\hline Sample codes & \multicolumn{1}{|c|}{ Isolated bacteria } & \multicolumn{1}{|c|}{ Strain } & Accession No. \\
\hline B1 & Alcaligenes faecalis & TRB-7 & MH109290.1 \\
B7 & & 16S ribosomal RNA gene, partial sequence & \\
\hline B2 & & & \\
& $\begin{array}{l}\text { Pseudomonas } \\
\text { anguilliseptica }\end{array}$ & $\begin{array}{l}\text { D4029 } \\
16 S \text { ribosomal RNA gene, partial sequence }\end{array}$ & FJ161260.1 \\
\hline B4 & Pseudomonas aeruginosa & $\begin{array}{l}\text { CIFRI DTSBI } \\
\text { 16S ribosomal RNA gene, partial sequence }\end{array}$ & JF784011.1 \\
\hline B5 & $\begin{array}{l}\text { Pseudomonas } \\
\text { oryzihabitans }\end{array}$ & $\begin{array}{l}\text { KCBOO5 } \\
\text { 16S ribosomal RNA gene, partial sequence }\end{array}$ & FJ824120.1 \\
\hline B6 & Alcaligenes sp. & JLT1515 & KX989249.1 \\
& & 16 S ribosomal RNA gene, partial sequence & \\
\hline
\end{tabular}


Multi-Drug Resistance Genes associated with some Gram-Negative Bacterial Isolated from Shellfish in Iko and Douglas River Estuaries, in Nigeria

\begin{tabular}{|l|l|l|l|}
\hline B8 & Alcaligenes faecalis & $\begin{array}{l}\text { BT10 } \\
16 \text { S ribosomal RNA gene, partial sequence }\end{array}$ & KY066459.1 \\
\hline B9 & Vibrio sp. & $\begin{array}{l}\text { PrVy108 } \\
16 \text { S ribosomal RNA gene, partial sequence }\end{array}$ & MF948980.1 \\
\hline B10 & Providencia vermicola & $\begin{array}{l}\text { B u15_38 } \\
16 \text { S ribosomal RNA gene, partial sequence }\end{array}$ & KY671146.1 \\
\hline B11 & Pseudomonas xiamenensis & $\begin{array}{l}\text { C10-2 } \\
16 S \text { r RA gene, partial sequence }\end{array}$ & NR_043533.1 \\
\hline B12, B17 & Providencia stuartii & $\begin{array}{l}\text { DMC-28b } \\
16 S \text { rRA gene, partial sequence }\end{array}$ & MH150796.1 \\
\hline B13 & Pseudomonas aeruginosa & JB2 chromosome, complete genome & CP028917.1 \\
\hline B14 & Pseudomonas aeruginosa & $\begin{array}{l}\text { N15-01092 } \\
\text { Complete sequence }\end{array}$ & CP012901.1 \\
\hline B16 & Paenalcaligenessp. & $\begin{array}{l}\text { UN24 } \\
16 S \text { ribosomal RNA gene, partial sequence }\end{array}$ & KP277115.1 \\
\hline B23 & Providencia rettgeri & $\begin{array}{l}\text { B5 } \\
16 S \text { ribosomal RNA gene, partial sequence }\end{array}$ & KY206744.1 \\
\hline
\end{tabular}

Figure 1 is a photograph of the agarose gel electrophoresis amplifying the $16 \mathrm{~S}$ rRNA gene of the bacterial isolates. Lanes 2, 3, 4, 5, 6, 7, 8, 9 and 10 on the gel picture shows the bacteria that harbour the 16S rRNA genes with base pair 1500.

All the 135 of the pathogenic Gram-negative bacterial isolates -were tested against thirteen Table2. Antimicrobial resistance profiles of the bacteria isolated from shellfish commonly used antibiotics in Table 2 . The least potent antibiotics against all the Gram-negative bacteria were cefepime, imipenem, ciprofloxacin, chloramphenicol and trimethoprim- sulfamethoxazole. -Amikacin and the quinolones had significant activity against Pseudomonas, Alcaligenes and Vibrio species.

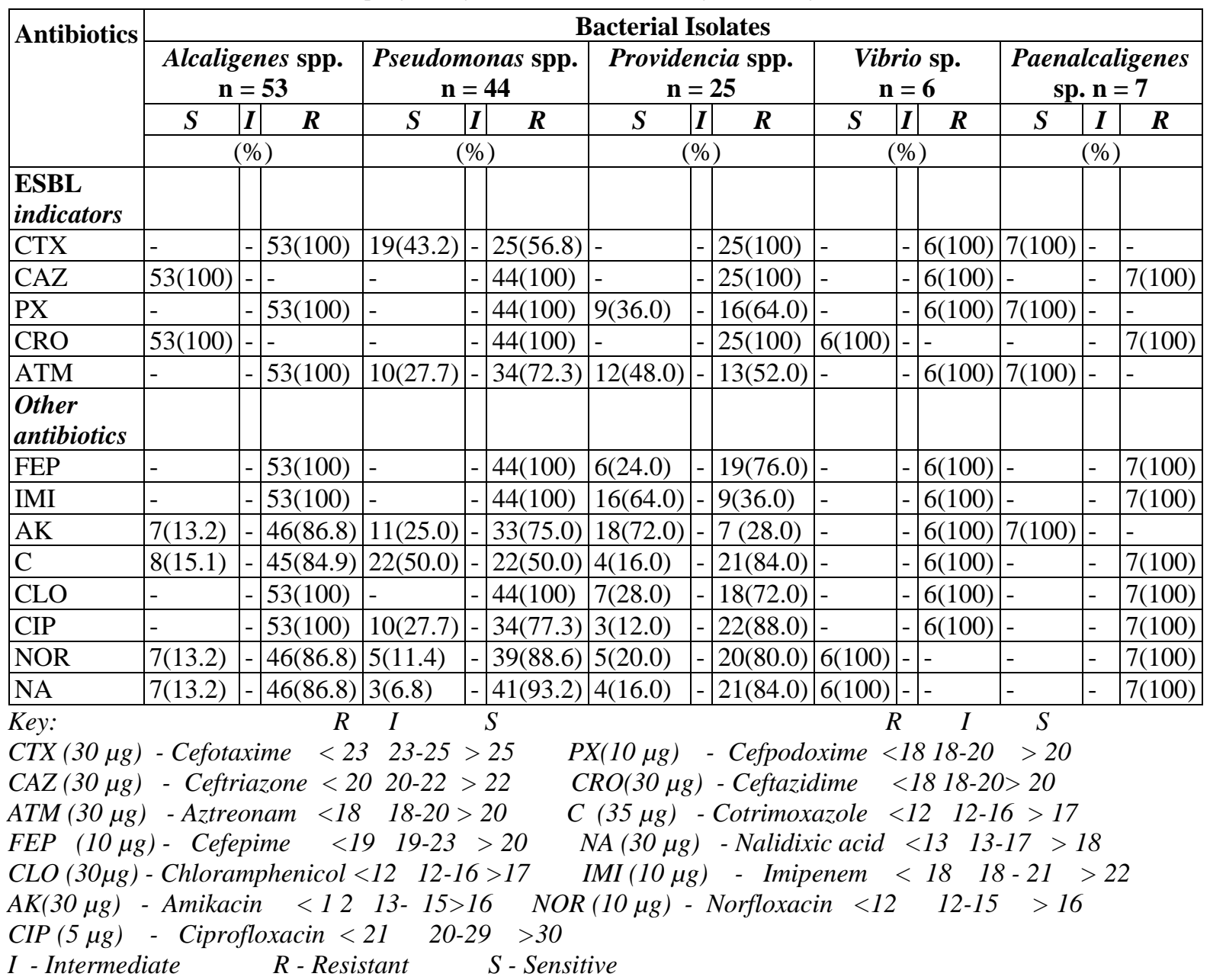

Twelve of the isolates had MARI >0.6 - 0.7, 34 isolates had >0.7-0.8, 35 to >0.8-0.9 and 54 had >0.9-1.0 (Table 3). Alcaligenes spp. had MARI of 38 (70.4\%) and the least was 5(41.70\%) for Pseudomonas spp. 
Multi-Drug Resistance Genes associated with some Gram-Negative Bacterial Isolated from Shellfish in Iko and Douglas River Estuaries, in Nigeria

Table3. Multiple antibiotic resistance index of the isolates in shellfish by genera

\begin{tabular}{|l|l|l|l|l|l|}
\hline \multicolumn{1}{|c|}{ Isolated bacteria } & \multicolumn{1}{|c|}{$\mathbf{0 . 5}-\mathbf{0 . 6}$} & \multicolumn{1}{|c|}{$>\mathbf{0 . 6}-\mathbf{0 . 7}$} & \multicolumn{1}{|c|}{$>\mathbf{0 . 7}-\mathbf{0 . 8}$} & \multicolumn{1}{|c|}{$>\mathbf{0 . 8}-\mathbf{0 . 9}$} & \multicolumn{1}{c|}{$>\mathbf{0 . 9}-\mathbf{1 . 0}$} \\
\hline Pseudomonas spp. & $0(0.00)$ & $5(41.70)$ & $12(35.30)$ & $10(28.60)$ & $15(29.63)$ \\
\hline Alcaligenesspp. & $0(0.00)$ & $7(58.33)$ & $0(0.00)$ & $8(22.70)$ & $38(70.40)$ \\
\hline Providencia spp. & $0(0.00)$ & $0(0.00)$ & $16(47.10)$ & $10(28.60)$ & $0(0.00)$ \\
\hline Vibrio sp. & $0(0.00)$ & $0(0.00)$ & $6(17.70)$ & $0(0.00)$ & $0(0.00)$ \\
\hline Paenalcaligenes sp & $0(0.00)$ & $0(0.00)$ & $0(0.00)$ & $7(20.00)$ & $0(0.00)$ \\
Total & $\mathbf{0 ( . 0 0 )}$ & $\mathbf{1 2}(\mathbf{8 . 9 0})$ & $\mathbf{3 4}(\mathbf{2 5 . 2 0})$ & $\mathbf{3 5}(\mathbf{2 6 . 0 0})$ & $\mathbf{5 3 ( 3 9 . 3 0 )}$ \\
\hline
\end{tabular}

$\begin{array}{llllllllllll}1 & 2 & 3 & 4 & 5 & \text { L } & 6 & 7 & 8 & 9 & 10 & 11\end{array}$

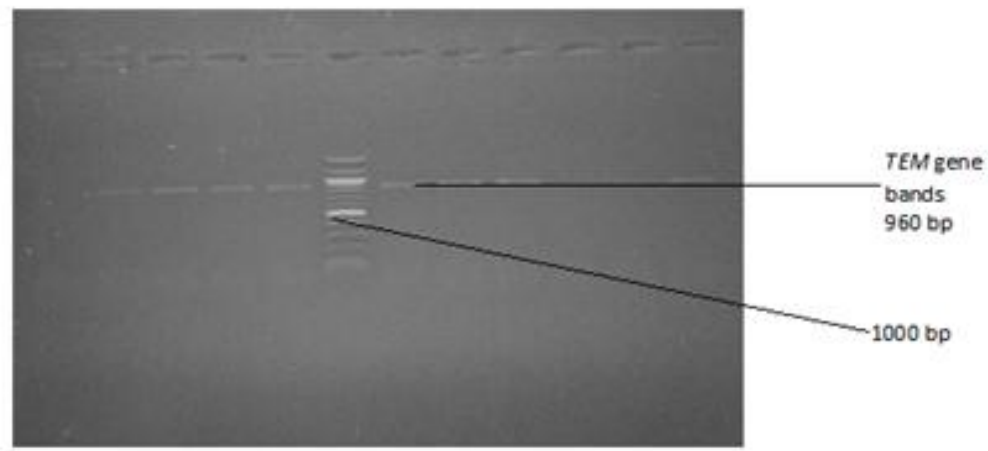

Fig2. Agarose gel electrophoresis showing the amplified TEM genes of the bacterial isolates. Lane L represents the 1000bp molecular ladder, lanes 2-8, 12, 13, 17, 21 and 23 showed TEM bands (960 bp).

As shown in Figure 2 -the agarose gel electrophoresis for the amplification of - the TEM gene of the bacterial isolates, - Lane $\mathrm{L}$ represents the $1000 \mathrm{bp}$ molecular ladder, lanes
$2,3,4,5,7,7,8,12,13,17,21$ and 23 show the amplified TEM bands (960 bp). The bacterial isolates positive for the TEM gene- are presented in Table 4.

Table4. ESBL/PMQR genes among the bacterial isolates in shellfish

\begin{tabular}{|c|c|c|c|c|c|c|}
\hline \multirow{2}{*}{ Genes } & \multicolumn{5}{|c|}{ Bacterial Isolates } & \multirow[b]{2}{*}{$\begin{array}{l}\text { Total no/ \% } \\
\text { positive }\end{array}$} \\
\hline & $\begin{array}{c}\text { Alcaligenesspp.(\%) } \\
\mathrm{n}=53\end{array}$ & $\begin{array}{c}\text { Pseudomonas } \\
\text { spp. (\%) } \\
\text { n }=44\end{array}$ & $\begin{array}{c}\text { Providencia } \\
\text { spp. }(\%) \\
\text { n }=25\end{array}$ & $\begin{array}{l}\text { Vibrio } \\
\text { sp. }(\%) \\
\mathrm{n}=6\end{array}$ & $\begin{array}{c}\text { Paenalcaligenes } \\
\text { sp. } \\
\mathrm{n}=7(\%)\end{array}$ & \\
\hline VIM & $15(28.30)$ & $15(34.10)$ & $25(100)$ & $6(100)$ & $7(100)$ & $68(50.3)$ \\
\hline TEM & $53(100)$ & $37(84.10)$ & $21(84.00)$ & - & - & $111(82.2)$ \\
\hline SHV & $53(100)$ & $7(15.90)$ & $4(16.00)$ & $6(100)$ & - & $70(51.8)$ \\
\hline$\overline{V E B}$ & - & - & - & - & - & - \\
\hline QnrB & $15(28.20)$ & $16(36.30)$ & 11(84.00) & $6(100)$ & $7(100)$ & $55(40.7)$ \\
\hline QnrS & - & - & & - & - & - \\
\hline QnrA & & - & - & - & - & - \\
\hline
\end{tabular}

Extended spectrum beta-lactamase genes Key:

VIM - Vimentin, TEM - Temoneria, SHV - sulfhydryl reagent variable

QnrS - Quinolone resistance genes SQnrB - Quinolone resistance genes B

$P M Q R$ - Plasmid-mediated quinolone resistance $-=$ Negative result

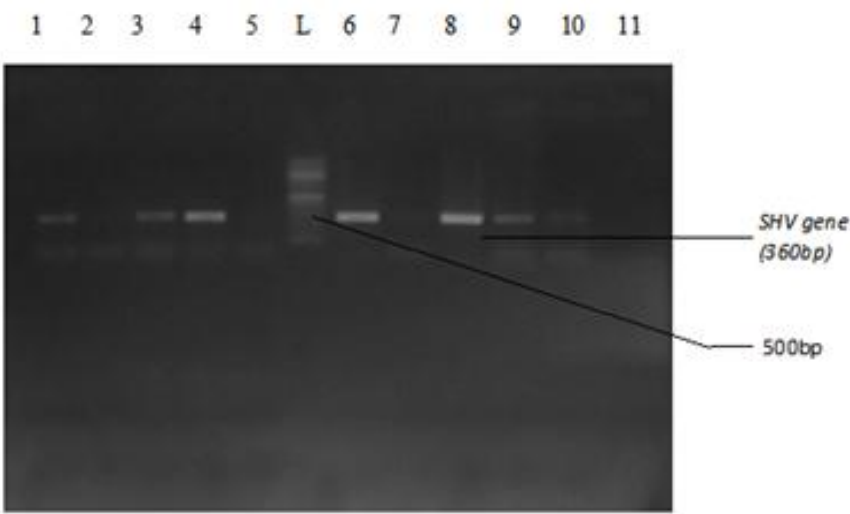

Fig3. Agarose gel electrophoresis showing the amplified SHV genes (360bp) of the bacterial isolates. Lane L represents the 500bp molecular ladder, lanes 1, 3, 4, 6, 8, 9 and 10 showed SHV bands (360 bp). 
Figure 3 shows the agarose gel electrophoresis of the amplified $S H V$ gene $(360 \mathrm{bp})$ of the bacterial isolates, Lane $\mathrm{L}$ shows the $500 \mathrm{bp}$ molecular ladders, lanes $1,3,4,6,8,9$ and 10 show the $S H V$ bands (360 bp). The $S H V$ positive isolates are listed in Table 4.

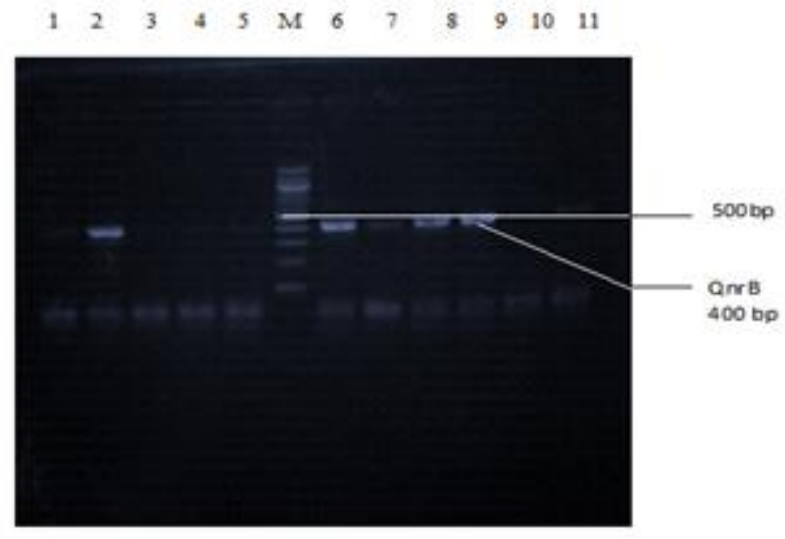

Fig4. Agarose gel electrophoresis showing the amplified QnrB gene (400bp) of the bacterial isolates. Lane L represents the 500bp molecular ladder, lanes 2, 6, 8, 9, 12, 13, 14, 16, 17, 21, 23 showed qnrb bands (400 bp)

The agarose gel electrophoresis amplifying the $q n r \mathrm{~B}$ gene of the bacterial isolates is presented on -Figure 4, Lane L represents the $500 \mathrm{bp}$ molecular ladder, Lanes $2,6,8,9,12,13,14$, $16,17,21$, and 23 show the $q n r \mathrm{~B}$ bands with molecular weight $400 \mathrm{bp}$. Details of theamplified isolates are shown in Table 4.

\section{DISCUSSION}

The pathogenic Gram-negative bacteria isolated in this study is an evidence of active, - high contamination of the coastal Calabar estuaries and portends a significant health risks associated with shellfish consumption in Nigeria. Unsafe food containing harmful bacteria, viruses, parasites and in some instance chemical substances, are reported causes more than 200 diseases - ranging from diarrhoea to cancers [2]. The increasing emergence of Gram-negative bacteria that are resistant to essentially all the available antimicrobial agents and the role of the aquatic environments in its dissemination represents an enormous public health threat worldwide [17,34].

Seafood is not only a recognized source of various food borne bacterial diseases, it also acts as an identified vehicle for dissemination of multidrug-resistant bacteria of clinical importance $[35,36]$. Consequently, the prevalence of AMR bacteria in seafood is of increasing importance attributable to the growing consumption of seafood worldwide [36]. Regular survey of antimicrobial resistance of bacterial pathogens from aquatic environments has been advocated as a feasible way of checking and reducing the passage of clinically important AMR from aquatic to environment [11]. In the present study, we analyzed the antimicrobial resistance of some Gram-negative bacterial isolated from Shellfish and found multiple antibiotic resistance. In this study, the following bacteria genera and species: Pseudomonas spp., Alcaligenes spp., Providencia spp., Vibrio sp., Paenalcaligenes sp. Some of these bacteria such as the Vibrio spp., a Gram negative enteropathogenic bacterium inhabiting estuarine ecosystems, is a major cause of foodborne illness associated with the consumption of raw or undercooked contaminated seafood or shellfish [37]. All the bacterial pathogens found in this study have been previously linked with commonly consumed shellfish in South Western Nigeria [38]. Severally, it has been documented that the pathogens isolated in our study are clinically relevant bacterial species found in seafood that could cause foodborne disease and other many health problems [35]. Our findings of mutli-drug resistance in this study adds to the growing global concern among the medical and scientific community over the increasing spread of bacterial resistance in the natural environment [39]. Similarly, alarming is the fact that the spread and maintenance of clinicallyrelevant Antibiotic Resistant Bacterial (ARB) in the environment including the estuaries is known to closely correlate with human antimicrobial consumption pattern due mainly to the unrestricted, overuse and misuse antimicrobials [39, 40].

Our results revealed that all the Gram-negative bacterial isolates from shellfish showed significant resistance against ciprofloxacin, chloramphenicol, trimethoprim-sulfamethoxa 
zole, cefepime and imipenem. This is in consonance with previously reported resistance of Gram-negative bacteria in shellfish to chloramphenicol, ciprofloxacin, tetracycline and trimethoprim-sulfamethoxazole [41]. We detected $72 \%$ resistance by Gram-negative bacterial isolates from shellfish to chloramphenicol. The observed diminished potency and resistance of some Gram-negative bacterial strains to antibiotics such as chloramphenicol, ciprofloxacin, tetracycline and trimethoprim-sulfamethoxazole is comparable to other earlier report of very low susceptibility rates of $8.6 \%$ for chloramphenicol and $3 \%$ to ciprofloxacin and trimethoprimsulfamethoxazole by some Gram-negative bacteria [42].

Carbapenems were reported to have high activity against Gram-negative bacteria and had at a time remained the drug of choice for treating stubborn infections [43]. Contrarily, resistance of Gram-negative bacteria to carbapenems has recently become very widespread [42]. Marked resistance to imipenem was observed in this study, only Providencia species had demonstrable susceptibility of $36 \%$ to the imipenem antibiotics. This is in conformity to the designation of Providencia species as one of the members of the Enterobacteriaceae species that have intrinsic imipenem resistance [45].

From our results, Pseudomonas species showed varying multiple-drug resistance to nalidixic acid (93\%), chloramphenicol (100\%) and trimethoprim -sulfamethoxazole (50\%) agreeing therefore with prior report from Nigeria on the resistance of Pseudomonas species to nalidixic acid, chloramphenicol and trimethoprimsulfamethoxazole [46]. We observed that Vibrio species were susceptible (100\%) to the norfloxacin (quinolones), nalidixic acid and ceftazidime but equally resistant $(100 \%)$ to the ESBL indicators and all other antibiotics tested. The observed susceptibility to ceftazidime by Vibrio species in this study differ from an earlier report of the resistance of pathogenic Vibrios in shellfish to ceftazidime from a similar study [47].

In this study, the Gram-negative bacterial isolates from shellfish exhibited multiple resistance to many commonly used antibiotics and most of them tested positive for ESBLproduction. While the Pseudomonas species were resistant (100\%) to Ceftriazone (CAZ (30 $\mu \mathrm{g}$ ) and Ceftazidime (CRO $30 \mu \mathrm{g}$ ), the Alcaligenes species on the other hand were susceptible $(100 \%)$ to both antimicrobial agents. The antimicrobial pattern for the Pseudomonas species in this study is at variance with a similar reported resistance pattern of Pseudomonas species [42]. Although the Alcaligenes species and Vibrio species were susceptible $(100 \%)$ to Ceftazidime, resistance $(100 \%)$ to the same antimicrobial agent were shown by Providencia, Paenalcaligenes and Pseudomonas species. Our result shows that ceftazidime was the most potent antibiotics (susceptibility 100\%) for Vibrio species and is in agreement with previous documented excellent activity of ceftazidime against Vibrios species [48]. Furthermore, we detected resistance to cefotaxime (CTX $30 \mu \mathrm{g}$ ) amongst the Vibrios, Alcaligenes and Providencia species. Interestingly, the Vibrio isolates from shellfish in this study exhibited cefotaxime and ceftazidime antimicrobial patterns distinct from that of an earlier comparable study [49].

It has been opined that the spread of antibioticresistant bacteria in the aquatic environment may have originated from the indiscriminate use of antibiotics, the release of untreated sewage containing antibiotic residues and from resistant bacteria from humans and animals [50]. Also, of notable concern is the fact that aquatic bacteria interact and may exchange resistance genes freely with their close neighbours and distant relatives which may lead to the acquisition of multiple antibiotic-resistant mechanisms by human pathogens [51]. This means that resistance genes can be transferred to other clinically important bacteria making antibiotics treatments ineffective as a result of acquired resistance by pathogens $[4,10,12,52]$.

In the present study, all the isolates from our shellfish samples had MAR indices > 0.6, portraying high antibiotics use and also high selective pressure in the environment. MAR index of 0.2 is the cut-off point normally used to discriminate between low and high-risk regions in areas where antibiotics are overused [53].

We found that 12 isolates had MARI $>0.6-0.7$, 34 isolates had $>0.7-0.8,35$ to $>0.8-0.9$ and the remaining 54 isolates had >0.9-1.0 (Table 3). Alcaligenes spesies had MARI of 38 (70.4\%) whereas, Pseudomonas species had the least MARI of $5(41.70 \%)$. These results agree with the reported high antibiotic resistance, multiple antibiotic resistance index (MAR1) and the possession of MAR genes by some of the bacterial isolates $[54,55]$. 
This study observed that Alcaligenes and Pseudomonas species expressed VIM, TEM and SHV genes, Vibrio species expressed VIM and SHV, Providencia species expressed TEM and SHV genes while Paenalcaligenes species expressed only VIM gene. However, VEB gene was not detected in any of the isolates. The Gram-negative bacteria showed resistance to cefotaxime, ceftriazone, ceftazidime, monobactam (aztreonam). Similarly, this study also showed that $82.2 \%$ of the isolates expressed TEM gene, $51.8 \%$ expressed SHV and 50.3\% for VIM genes. No VEB genes were detected among the isolates. Most ESBL-producing organisms inhabit the bowel, blood, skin, wounds, urine, sputum and the ESBL-genes are capable of spreading directly by person-toperson contact and indirectly by contaminated surfaces to a person [56, 57]. ESBL genes production is considered a public health menace because the genes are known to be capable of conferring resistance to the beta-lactam antibiotics and thereby rendering the drugs ineffective for treatment.

Among the qnr positive isolates we detected, $40.7 \%$ expressed qnrB gene while none expressed qnrS and qnrA genes. Providencia, Pseudomonas, Vibrio, Alcaligenes and Paenalcaligenes species were all qnr positive. The qnr has been incriminated as key determinants in mutation and alteration in the synthesis of DNA gyrase and topoisomerase iv capable of altering the binding sites of quinolones, making the quinolones/ fluoroquinolones antibiotics ineffective [58]. Our detection of the qnr in the Providencia species corroborates a previously first reported detection of PMQR gene in Providencia rettgeri [59]) and the PMQR gene is now known to significantly correlate with other antimicrobial genes such as ESBL genes [60, 61].

Remarkably, the antibiotic resistance exhibited by the most of the Gram-negative bacterial isolates from shellfish as observed from the ESBL indicators susceptibility tests may have been conferred by a mechanism for $\beta$-lactam resistance as evidenced by higher ESBL genes detection rates in comparison with other published report 50, 62].

\section{CONCLUSION}

This study identified amikacin and imipenem as the most effective antibiotics against Providencia spp. while cefepime, chloramphenicol, ciprofloxacin and trimethoprim-sulfamethoxazole were the least effective drugs. The multiple antibiotics resistance indices of the isolates showed that with exceptions to Paenalcaligens spp. all other isolated Gram-negative bacteria were resistant to all the antimicrobials tested. Fifty-four shellfish isolates in this study showed MARI greater than 0.9 while none of the isolates showed MARI of $0.5-0.6$ or less. The most prevalent ESBL genes from this study were TEM gene $82.2 \%$, SHV had $51.9 \%$ and $50.4 \%$ for VIM gene. Nonetheless, none of the Gramnegative bacteria expressed $V E B$ gene. This study also showed that $40.7 \%$ of the bacterial isolates expressed $q n r \mathrm{~B}$ genes which conferred resistance to quinolones, fluoroquinolones antibiotics. The genera isolated in this study were multi-drug resistant bacteria. The contamination of the shellfish with human pathogens indicates direct faecal or other body wastes contamination of the creeks, unhygienic method of harvesting, handling, transportation, processing. The extensive use, misuse and abuse of antibiotics is a clear pointer to the high MARI observed in this study which leads to high mortality and treatment failure.

\section{REFERENCES}

[1] El-Sayed, M. H. (2019). Occurrence of Multidrug Resistant Bacteria in Some Selected Street Food Samples. Journal of Pharmaceutical Research International, 31(1), 1-8. https://doi. org/10.9734/jpri/2019/v31i130288

[2] WHO (2020). https://www.who.int/news-room/ fact-sheets/detail/food-safety

[3] Algammal, A.M., Mabrok, M., Sivaramasamy, E. Youssef, Fatma M., Atwa, Mona H., Elkholy, Ali W., Hetta, Helal F., Hozzein, Wael N. (2020). Emerging MDR-Pseudomonas aeruginosa in fish commonly harbor $o p r \mathrm{~L}$ and tox $\mathrm{A}$ virulence genes and $b l a_{\mathrm{TEM}}, b l a_{\mathrm{CTX}-\mathrm{M}}$, and tetA antibiotic-resistance genes. Sci Rep 10, 15961. https:// doi.org/10.1038/s41598-02072264-4

[4] Hembach, N.; Schmid, F.; Alexander, J.; Hiller, C.; Rogall, E.T.; Schwartz, T. (2017). Occurrence of themcr-1colistinresistance gene and other clinically relevant antibiotic resistance genes in microbial populations at different municipal wastewater treatment plants in Germany.Front. Microbiol.,8, 1282. [CrossRef] [PubMed]

[5] De Kraker MEA, Stewardson AJ, Harbarth S (2016) Will 10 Million People Die a Year due to Antimicrobial Resistance by 2050? PLoS Med 13(11): e1002184. https://doi.org/10. 1371/ journal .pmed.1002184. 
Multi-Drug Resistance Genes associated with some Gram-Negative Bacterial Isolated from Shellfish in Iko and Douglas River Estuaries, in Nigeria

[6] Woolhouse, M. Antimicrobial resistance in humans, livestock and the wider environment. J. High Energy Phys. 2015, 6, 1575-1589. [Google Scholar] [CrossRef] [PubMed].

[7] Leonard, A.F.C.; Zhang, L.; Balfour, A.J.; Garside, R.; Gaze, W.H. Human recreational exposure to antibiotic resistant bacteria in coastal bathing waters. Environ. Int. 2015, 82, 92-100. [Google Scholar] [CrossRef] [PubMed].

[8] Xu, Y.; Guo, C.; Luo, Y.; Lv, J.; Zhang, Y.; Lin, H.; Wang, L.; Xu, J. Occurrence and distribution of antibiotics, antibiotic resistance genes in the urban rivers in Beijing, China. Environ. Pollut. 2016, 213, 833-840. [Google Scholar] [CrossRef] [PubMed]

[9] Bassetti M, Peghin M, Vena A and Giacobbe DR (2019) Treatment of Infections Due to MDR Gram-Negative Bacteria. Front. Med. 6:74. doi: 10.3389/fmed.2019.00074).

[10] Pérez-Etayo L, González D, Leiva J, Vitas AI. (2020). "Multidrug-Resistant Bacteria Isolated from Different Aquatic Environments in the North of Spain and South of France" Microorganisms 8, no. 9: 1425.

[11] Preena, P.G.; Arathi, D.; Raj, N.S.; Kumar, T.V.A.; Raja, S.A.; Reshma, R.N.; Swaminathan, T.R. Diversity of antimicrobialresistant pathogens from a freshwater ornamental fish farm. Lett. Appl. Microbiol. 2019, 71, 108-116

[12] Guo, M.T.; Yuan, Q.-B.; Yang, J. (2013) Microbial selectivity of UV treatment on antibiotic-resistant heterotrophicbacteria in secondary effluents of a municipal wastewater treatment plant. Water Res., 47, 6388-6394. [CrossRef]

[13] Hariharan, H. \& Amadi, V. Shellfish as reservoirs of bacterial pathogens. Journal of Coastal Life Medicine, 2016; 4(4): 253-258.

[14] Nijsingh, N., Munthe, C., Lindblom, A., Åhrén, C. (2020). Screening for multi-drug-resistant Gram-negative bacteria: what is effective and justifiable?. Monash Bioeth. Rev. 38, 72-90 (2020). https://doi.org/10.1007/s40592-020-001 13-1

[15] Bosch, T., S.P. Lutgens, M.H. Hermans, P.C. Wever, P.M. Schneeberger, N.H. Renders, and S. Witteveen. 2017. Outbreak of NDM-1producing Klebsiella pneumoniae in a Dutch hospital, with interspecies transfer of the resistance plasmid and unexpected occurrence in unrelated health care centers. Journal of Clinical Microbiology 55 (8): 2380-2390.

[16] Lindblom, A., K.K. Sriram, V. Müller, R. Öz, H. Sandström, C. Åhrén, and N. Karami. 2019. Interspecies plasmid transfer appears rare in sequential infections with extended-spectrum $\beta$ lactamase

(ESBL)-producing
Enterobacteriaceae. Diagnostic Microbiology and Infectious Disease 93 (4): 380-385.

[17] Zeinab Breijyeh, Buthaina Jubeh, Rafik Karaman Resistance of Gram-Negative Bacteria to Current Antibacterial Agents and Approaches to Resolve It. Molecules. 2020 Mar; 25(6): 1340. Published online 2020 Mar 16. doi: $10.3390 /$ molecules 25061340

[18] Ruppé, E.; Woerther, P.-L.; Barbier, F. Mechanisms of antimicrobial resistance in Gram-negative bacilli. Ann. Intensiv. Care2015,5, 61Breijyeh Z, Jubeh B, Karaman R. Resistance of Gram-Negative Bacteria to Current Antibacterial Agents and Approaches to Resolve It. Molecules. 2020; 25(6):1340.

[19] Wamala, S.P., Mugimba, K.K., Mutoloki, S Evensen, O., Mdegela, R., Byarugaba, D. K., Sorum, H. (2018). Occurrence and antibiotic susceptibility of fish bacteria isolated from Oreochromis niloticus (Nile tilapia) and Clarias gariepinus (African catfish) in Uganda. Fish Aquatic Sci 21, 6 (2018). https://doi.org/10.1186

[20] Sanjit Singh, Asem; Lekshmi, Manjusha; Prakasan, Sreepriya; Nayak, Binaya B.; Kumar, Sanath. 2017. "Multiple Antibiotic-Resistant, Extended Spectrum- $\beta$-Lactamase (ESBL)Producing Enterobacteria in Fresh Seafood" Microorganisms 5, no. 3: 53.

[21] Das, U.N., Singh, A.S., Lekshmi, M. et al. Characterization of bla $\mathrm{NDM}$-harboring, multidrug-resistant Enterobacteriaceae isolated from seafood. Environ Sci Pollut Res 26, 24552463 (2019). https://doi.org/10.1007/s11356-018$3759-3$

[22] Stanton, I.C., Bethel, A., Leonard, A.F.C. et al. What is the research evidence for antibiotic resistance exposure and transmission to humans from the environment? A systematic map protocols. Environ Evid 9, 12 (2020). https://doi.org/10.1186/s13750-020-00197-6.

[23] Md Anwarul Azim Majumder, Sayeeda Rahman, Damian Cohall, Ambadasu Bharatha, Keerti Singh, Mainul Haque, and Marquita Gittens-St Hilaire. Antimicrobial Stewardship: Fighting Antimicrobial Resistance and Protecting Global Public Health. Infect Drug Resist. 2020; 13: 4713-4738.

[24] Tawari, C. C. \& Davies, O. Effectiveness of agricultural agencies in fisheries production andmanagement in Niger Delta, Nigeria. Ozean Journal of Applied Sciences, 2009; 2(4).

[25] ISO, 6579 Microbiology 4th Ed. General guidance on methods for the detection ofSalmonella. Geneva, Switzerland: International Organization for Standardization, 2003;1-122.

[26] Farmer, J. J., Janda, M., Brenner, F. W., Cameron, D. N., Brikhead, K. M. \& Genus, I. 
Multi-Drug Resistance Genes associated with some Gram-Negative Bacterial Isolated from Shellfish in Iko and Douglas River Estuaries, in Nigeria

Vibrio pacini1854, 411AL. In: Brenner, D. J., Kreig, N. R., Staley, J. T. (Eds.). Bergey's Manual of Systemic Bacteriology. The Proteobacteria, Part B. The Gammaproteo Bacteriria, 2nd Edn. New York: Springer, 2005;2, 494-546.

[27] Cheesbrough, M. District laboratory practices in tropical countries, Part II. United Kingdom: Cambridge University Press, 2002;182-187.

[28] MacFaddin, J.F. (2000) Biochemical Tests for Identification of Medical Bacteria. 3rd Edition, Lippincott Williams \& Wilkins, Philadelphia.

[29] Conlan S, Kong HH, Segre JA (2012) SpeciesLevel Analysis of DNA Sequence Data from the NIH Human Microbiome Project. PLoS ONE 7(10): e47075. https://doi.org/ 10.1371/ journal. pone.0047075.

[30] Fallah, H. S., Asgharpour, F., Naderian, Z. \& Moulana, Z. Isolation and determination of antibiotics resistance patterns in non-typical Salmonella species isolated from chicken. International Journal of Enteric Pathogens, 2013; 1(1):17-21

[31] Weinstein, M.P., Patel, J. B., Campeau, S., Conville, P., Doern, C., Eliopolus, G.M., Galas, M.F., Humphries, R.M., Jenkins, S.G., Kircher, S.M. \& Lewis, J.S. Performance standard for antimicrobial disk susceptibility tests (13th Edn). Clinical Laboratory Standards Institute 2018;standard M02.

[32] Mafu, N. C., Pironcheva, G. \& Okoh, A. I. Genetic diversity and in vitro antibiotic susceptibilitysources in the Eastern Cape province of South Africa. African Journal of Biotechnology, 2009;8, 1263-1269.

[33] Dashti, A.A., Jadaon, M.M., Abdulsamand, A.M., Dashti, H. Heat treatment of bacteria: A simple method of DNA extraction for molecular techniques. Journal of the Kuwait Medical Association (2009); 41(2).

[34] Berendonk, T. U., Manaia, C. M., Merlin, C., Fatta-Kassinos, D., Cytryn, E., Walsh, F., et al. (2015). Tackling antibiotic resistance: the environmental framework. Nat. Rev. Microbiol. 13, 310-317. doi: 10.1038/nrmicro 3439.

[35] Omoya F. O. and Ajayi A. T. (2020). Assessment of the microbial quality of seafood and effects of salt concentration and temperature on isolated microorganisms, Journal of Microbiology and Antimicrobials, Vol.12(1), pp. 17-31,doi.org/ 10.5897/ JMA 2019.0417.

[36] Brisabois A, Svanevik C, Price-Hayward M, Valeria Bortolaia V, Leoni F, Sophie Granier S, Mario Latini M, Chiara Francesca Magistrali CF, Lunestad B, Peyrat M, (2019). ASK network for antimicrobial resistance in seafood as common ground for knowledge exchange, Research Report, pp.1-36 HAL Id: anses-
02437102, Available: https://hal-anses. archives -ouvertes.fr/ anses-02437102.

[37] Xinjie S, Jinlin Z, Weisen Y, Xuexiang S, Yongning $\mathrm{W}(2020)$. Occurrence and Identification of Pathogenic Vibrio Contaminants in Common Seafood Available in a Chinese Traditional Market in Qingdao, Shandong Province, Frontiers in Microbiology 11: 1488 , DOI=10.3389/fmicb.2020.01488.

[38] Afolayan O.A., Moruf R.O. and Lawal-Are A.O. (2020). Bacterial contamination and heavy metal residues in frozen shellfish retailed within Lagos Metropolis, Nigeria Science World Journal Vol. 15(No 1)11-14.

[39] Serweci' nska L . (2020). Antimicrobials and Antibiotic-Resistant Bacteria:A Risk to the Environment and to Public Health, Water2020, 12, 3313; doi:10.3390/w12123313

[40] Jechalke, S.; Heuer, H.; Siemens, J.; Amelung, W.; Smalla, K. Fate and effects of veterinary antibiotics in soil.Trends Microbiol.2017,22, 536-545.

[41] Amadi, V.A., Peterson, R., Mathew-Belmar, V., Sharma, R. \& Hariharan, H. Prevalence and antibiotic susceptibility of Gram-negative aerobic bacteria cultured from the intestine and hepatopancreas of blue land crab (Cardisomaguanhumi) in Grenada, West Indies, British Microbiological Resources Journal, 2015;5, 169-179.

[42] Rodriguez, A. I., Hariharan, H. \& Nimrod, S. Occurrence and antimicrobial drug resistance of potential bacterial pathogens from shellfish, including conchs (Strombusgigas) and whelks (Cittarium pica) in Grenada Webmed Central Microbiology, 2011; 2(5): WMC001 943.

[43] Livermore, D. M., Sefton, A. M. \& Scott, G. M. Properties and potential of Ertapenem. Journal of Antimicrobial chemotherapy, 2003; 52,331-334.

[44] Perez, F. \& Van, D. D. Carbapenem-resistant Enterobacteriaceae: A menace to our most vulnerable patients. Cleveland Clinic Journal of Medicine 2013;80 (4): 225-233.

[45] Lutgring, J.D. Carbapenem-resistant Entero bacteriaceae: An emerging bacterial threat. Semin. Diagn. Pathol. 2019, 36, 182-186.

[46] Akinbowale, O. L., Peng, H. \& Barton, M. D. Antimicrobial resistance in bacteria isolated from aquaculture sources in Australia. Journal of Applied Microbiology, 2006; 100(5).

[47] Sudha, S., Abdulla, M.H. \& Silvester, R. Prevalence and antibiotic resistance of pathogenic Vibrios in shellfishes from Cochin market. Indian Journal of Geo-Marine Sciences, 2014;43(5): 815-824.

[48] Haenen, O. L., Evans, J. J. \& Berthe, F. Bacterial infections from acquatic species: potential for and prevention of contact 
Multi-Drug Resistance Genes associated with some Gram-Negative Bacterial Isolated from Shellfish in Iko and Douglas River Estuaries, in Nigeria

zoonoses. Revue Scientifique et Technique, 2013; 32, 497-507.

[49] Letchumanan, V., Pusparajah, P., Tan, L. T., Yin, W., Lee, L. \& Chan, K. Occurrence and Antibiotic Resistance of Vibrio parahaemolyticus from shellfish in Selangor, Malaysia. Frontiers of Microbiology, 2015; 6, 1417-1435.

[50] Singh, A. S., Lekshmi, M., Prakasan, S., Nayak, B. B. \& Kumar, S. Multiple AntibioticResistant, Extended Spectrum $\beta$-Lactamase (ESBL)-Producing Enterobacteria in Fresh Seafood. Microorganisms, 2017;5, 53-63.

[51] Walsh, T.R. \& Toleman, M.A. The emergence of pan-resistant Gram-negative pathogens merits a rapid global political response. Journal of Antimicrobial Chemotherapy, 2012;67, 1-3.

[52] Lery, S. B. How misuse of antibiotics destroys their curative powers. The Antibiotic Paradox. UK: Oxford University Press, 2002; pp 39-41.

[53] Riaz, S., Faisal, M. \& Hasnain, S. Antibiotic susceptibility pattern and multiple antibiotic resistance (MAR) calculation of extendedspectrum $\beta$-lactamase (ESBL) producing Escherichia coli and Klebsiella species in Pakistan. African Journal of Biotechnology, 2011;10, 6325-6331.

[54] Olayinka, A.T., Olayinka, B.O \& Onile, B.A. Antibiotic susceptibility and plasmid pattern of Pseudomonas aeruginosa from the surgical unit of a University teaching hospital in Northcentral Nigeria, International Journal of Medical Science, 2009;1, 079-083.

[55] Solomon, L., Ogugbue, C. J. \& Okpokwasili, G. C. Antibiotic Resistance Profiles of Bacteria Associated with Fresh and Frozen Shrimp (Palaemonetes sp.) and Their Public Health Significance. International Journal of Scientific Research in Knowledge (IJSRK), 2013;1(10): 448-456.
[56] Bradford, P. A. Extended-Spectrum $\beta$ lactamases in the $21^{\text {st }}$ century. Characterization, epidemiology and detection of this important resistance threat. Clinical Microbiology Review, 2001;48, 933-951.

[57] Eja, M. E., Udoekong, N. S., Ikpeme, E. M. \& Enyi-Idoh, K. H. Antibiogram studies and extended-spectrum beta-lactamase activity profile of Salmonella-like species isolated from poultry soil of the University of Uyo, Nigeria. Malaysian Journal of Microbiology, 2012;8(4): 280-284.

[58] Jacoby, G. A., Strahilevitz, J. \& Hooper, D. C. Plasmid-mediated quinolone resistance. Microbiology Spectrum, 2014;2(5): PLAS-0062013.

[59] Yugendran, T. \& Harish, B. N. High incidence of plasmid-mediated quinolone resistance genes among ciprofloxacin-resistant clinical isolates of Enterobacteriaceae at a tertiary care hospital in Puducherry, India 2016; Peer J 4:e1995.

[60] Wu, J. J., Ko, W. C., Tsai, S. H. \& Yan, J. J. Prevalence of plasmid-mediated quinolone resistance determinants $Q n r A, Q n r B$, and $Q n r S$ among clinical isolates of Enterobactercloacae in a Taiwanese hospital. Antimicrobial Agents and Chemotherapy, . 2007;51, 1223-1227.

[61] Yang, H., Chen, H., Yang, Q., Chen, M. \& Wang, H. High prevalence of plasmid-mediated quinolone resistance genes $q n r$ and $a a c\left(6^{\prime}\right)-I b$ $\mathrm{cr}$ in clinical isolates of Enterobacteriaceae from nine teaching hospitals in China. Antimicrobial Agents and Chemotherapy, 2008; 52, 4268-4273.

[62] Zafer, M. M., Al-Agamy, M. H., ElMahallawy, H. A., Amin, M. A. \& Ashour, M. S. E. Antimicrobial Resistance Pattern and their Beta-Lactamase Encoding Genes among Pseudomonas aeruginosa strains isolated from cancer patients. BioMed Research International, 2014;29: 80-81.

Citation: Nsikan Samuel udoekong et al., "Multi-Drug Resistance Genes associated with some GramNegative Bacterial Isolated from Shellfish in Iko and Douglas River Estuaries, in Nigeria”, International Journal of Research Studies in Medical and Health Sciences. 2021; 6(4): 11-23. DOI: https://doi.org/ 10.22259/ijrsmhs.0604004

Copyright: (C) 2021 Nsikan Samuel udoekong et al., This is an open-access article distributed under the terms of the Creative Commons Attribution License, which permits unrestricted use, distribution, and reproduction in any medium, provided the original author and source are credited. 